\title{
Study on Washington's Economizing Economy Principle
}

\author{
Yuyan Zhao \\ Primary Education College \\ Linyi University \\ Linyi, Shandong, China 273400
}

\begin{abstract}
In an era of resource shortage, it is imperative to advocate saving and practice economy without a moment's delay. Therefore, economizing economy should be advocated in construction of national politics, economy, military and culture. This paper initially explores Washington's some practices of economical economy, some of which occur in American construction, hoping to provide some assistance and references for China's economy and thrift at the present stage.
\end{abstract}

Keywords-Washington; economizing economy

\section{INTRODUCTION}

The so-called economizing economy reasonably uses manpower, financial resources, material resources and other social resources and natural resources. The key is to control people's behavior and make various kinds of resources play their part enduringly. Economizing economy is the kind of saving conducted on the precondition that rightful need is met and it has consciousness. Theoretical basis of economizing economy is full consideration of the whole nature's bearing capacity, thus leaving sufficient room for sustainable development of society. A few days ago, according to the requirement that army goes in advance, the whole army's resource saving work started from grain-saving, water saving, power saving and oil saving to troops' infrastructure construction, military training, equipment support and management and other fields, producing good military, economic and social benefit and effectively promoting military's fighting capacity and capacity of support. From this, I think of Washington's economizing economy principle in American Revolution and at the primary stage of American independence, hoping to provide some references for China's economizing economy in military field at the present stage.

\section{THE REASON WHY WASHINGTON IMPLEMENTS ECONOMIZING ECONOMY}

George Washington is commander in chief of continental army during American Revolution and becomes the first president of America after independence. In war of independence, he commands continental army established in colonies in a hurry way and they have a war of eight years. Finally, he beats the number one military power in the world at that time - England and wins independence for America. No matter it is in mercurial independence war or at the crisisridden beginning of founding of America, Washington can always have the strategic insight of a militarist, be strategically situated, combine with America's national conditions, and consider long-term national development. He personally practices passing of American's new constitution and works out economical defense economy construction conception in practice, laying the foundation for establishment of America's military and economic system.

In 1750s, when participating in Indians' war in France, Washington finds that American militiamen have many shortcomings: For a long time, they don't have basic army discipline; soldiers fire casually after training and sleep at the post and shoot prey casually during marching; even army deserter only gets slight punishment. Washington points out "Militiamen can never satisfy your wish and you can't rely on them at all. They are stubborn and willful. They are often incited by officers and refuse to execute command. Sometimes they are absent without leave". According to America's traditional practice, militiaman's service period is very short, half of which is wasted on registration and on the way back home upon demobilization. Once the service period is due, no matter how critical the war situation is, militiaman still leaves the military and goes home. In addition, militiamen squander ammunition, weapons and various other equipment. They would rather starve to death than march with food on their back for a few days. When hungry, they kill cows, eat like a horse and continue to march. They are indifferent to civilians' safety. They are indolent and ignore military discipline. "They act in an arbitrary and reckless manner, come and go at will, and cast commands behind their back." In American Revolution, Washington dwells on serious harm of militiaman system's shortcomings many times. He thinks that if he continues to blindly "rely on militiamen, namely using a broken crane as a crutch", America's independent career definitely will fail. Combining with his own experiences and the widely spread idea of regular military money in society for a long time, Washington points out that more ammunition is wasted due to militiaman's lack of systematic training. In addition, militiaman's service period is short. Reasonless consumption of militiaman's gathering and repatriation further increases government's financial burden. Since militiaman's fighting capacity is bad, the loss of war is difficult to compute. As early as on Sept. 20, 1776, he points out "Militiaman's expense is vast and numerous and militiaman is unreliable. The later the parliament establishes a regular army, the more difficult it will be to establish and the more money it will 
cost." After illustrating importance of regular army many times, Washington gives a thought-provoking warning to continental congress: Without regular army, "perishment is doomed."

Perhaps Washington can't be called an economist, but he realizes that economy is the key overwhelming everything in American Revolution. As a politician, he looks far ahead and aims high. Based on this recognition, Washington calls for complete transformation of "militiaman type" continental army from the economic perspective again and again, and tries his best to improve American soldiers' salary during the war, thus producing an army that is good at fighting and is highly disciplined for America. It is exactly under the protection of this core army, America sticks to long fighting in the war, making people and the world see hope and winning more international support. As a result, America successfully defeats the strongest British army in the world. During the war, Washington reorganizes "militiaman type" continental army in economy, military and some other aspects. Through endeavor, finally he trains out a steel army that is highly discipline and is valiant in fighting. The army outlives test of warfare and becomes the firm foot stone for future American regular army. From then on, Washington always devotes himself to transformation of continental army into an army similar to European army. His efforts are not wasted. Although the population of continental army never exceeds British army, American army doesn't suffer a defeat in tactical intervention with British army. Washington's regular army is as excellent as British army in 1779 .

At the beginning of founding, America's situation is extremely complex and critical. After independence, America is weak with a population of less than three million. It has no navy force, it is heavily in debt in economy and it falls apart in politics. Each state acts as it pleases and confederate governmental power is weak. The eight-year independence war makes America full of holes in economy and national economy is at the point of breaking down. After the war, big bourgeoisie in northern America and southern slave owners intensify exploitation and oppression of people, resulting in inflation, soaring prices, frequent revolt and turmoil situation. Peasants and soldiers in various states ask for land, payment increase, debt relief and land tax and other levies. From 1783 to 1786 , since the government is behind in payment to soldiers, plenty of soldier revolts and demonstrations occur in various places of America. The 1783 Pennsylvania soldier rebellion even leads to occupation of parliament house in Philadelphia at one time.

At the same time, England, France, Spain and other big powers cast a greedy eye on the young republic. America faces a series of diplomatic difficulties. First, US-Britain relation is still tense. In military, although independence war is over and British army withdraws from America, British army still gathers in Canada and waits for the chance to attack, seriously threatening the new born United States of America. In economy, British maritime supremacy is the largest barrier to America's trade development. After independence, America loses those trade privileges owned by being a member of British empire. British government refuses to sign any trade treaty with America. Second, US-France relation is in a stalemate. France doesn't abide by clauses concerning
American independence and perimeter security in treaty of alliance of 1778. It fails to urge Britain to withdraw from stronghold in the north and it doesn't oppose Spain's boundary requirements. France is happy to see America in a split and weak state, in order to control America forever. The area on the west of Appalachian has become France's colony at that time. France tries its best to guard against America and prevent America from going west and France incites Indians to attack American soil. Third, US-Spain contradiction gets upgraded. South America is the domain of Spain as an old colonial power. Spain prevents American revolution storm from spreading to its own colonies. It also covets American territory and waits for chances to grab.

\section{ESTABLISHMENT OF ECONOMIZING ECONOMY PRINCIPLE}

Considering that America is surrounded by big powers' threat, it has to speed up national defense construction which definitely costs plenty of human power, financial resources and material resources. At that time, America can't afford the cost. Then, how to solve or remit the contradiction between great national defense and increase in national economic burden? Influenced by American traditional view, Washington also thinks that large quantities of regular army can do harm to national democracy and people's freedom. Since American economy is at the point of breaking down at that time, Washington thinks the nation can't afford the huge army's expense. However, due to the complex and critical domestic and overseas situation, it is clear that America has to have a regular army. In peaceful period, America has to rely on army to threaten Indians, protect domestic business activities and resist threats from Canada and Florida. In order to reduce increase of burden on national finance as much as possible, Washington sticks to the principle of emphasis on quality of army rather than quantity, and he points out "The army obtaining success is of great quality rather than great quantity." He proposes that the regular army should consist of four large units of infantry, one artillery group and one engineering team, 2630 soldiers in total. This small army "can be expanded" because officers occupy a very high proportion. Once war breaks out, America can rely on these officers as backbone to rapidly expand the army.

\section{SignifiCANCE OF ECONOMIZING ECONOMY PRINCIPLE}

Washington emphasizes the economizing economy national construction principle repeatedly. For example, in 1790 , he points out: "It is necessary to appropriately set up an army. Economy is very important." In his leaving office speech in 1796, Washington again warns American people with deep feeling: It is unnecessary to have an over large army which is harmful to freedom in any form of government, and it is especially harmful to freedom of the republic. Washington's practice of regarding expandable regular army as backbone and using financial resources and material resources as few as possible to build up national power conforms to America's national conditions at that time, deserving the credit. 


\section{CONCLUSION}

In his leaving office speech, Washington says: We should cherish our country's financial resource, because it is an important source of power and security. One method of saving financial resource is to use it as less as possible and maintain peace to avoid extra expenses. Please remember that timely allocation of funds to nip in the bud usually can avoid paying more to eliminate disasters. Also, we should avoid accumulation of debt. Therefore, we should reduce our expense and try to pay the debt brought by inevitable wars in peaceful period. Don't ruthlessly leave the debt which should be paid by ourselves to our descendants. Washington's economizing economy principle has great influence on America's later construction in various aspects.

\section{REFERENCES}

[1] Liu Zuochang. History of American Independence War[M]. Shanghai: East China People's Publishing House, 1954.

[2] T.O.Lloyd The British Empire (1558-1983)[M]. Oxford, 1984.

[3] Larry Searl, Veggli. History of American Army[M]. Beijing: Liberation Army Press.

[4] Yu Zhisen. American History Outline. East China Normal University, 1992.

[5] Moleisi. Fight for American Freedom. Sanlian Bookstore, Chinese Edition, 1957.

[6] J.H.Rose,eds. The Cambridge History of British Empire[M]. Cambridge 1929.

[7] Samuel Morison etc. Growth of United States of America(Volume 1). Tianjin People's Press, 1978 Edition.

[8] Clausewitz. On War(Volume 2). Liberation Army Press, 1964 Edition. 